\title{
A Tér és Társadalom 2016-ban
}

\author{
Space and Society in 2016
}

\section{CZIRFUSZ MÁRTON, TAGAI GERGELY}

\begin{abstract}
CZIRFUSZ Márton: tudományos munkatárs, MTA Közgazdaság- és Regionális Tudományi Kutatóközpont, Regionális Kutatások Intézete; 1112 Budapest, Budaörsi út 45.; adjunktus, Eötvös Loránd Tudományegyetem, Társadalom- és Gazdaságföldrajzi Tanszék; 1117 Budapest, Pázmány P. sétány 1/c.; czirfusz@rkk.hu

TAGAI Gergely: tudományos munkatárs, MTA Közgazdaság- és Regionális Tudományi Kutatóközpont, Regionális Kutatások Intézete; 1112 Budapest, Budaörsi út 45.; tagai@rkk.hu
\end{abstract}

Márton CZIRFUSZ: research fellow, Institute for Regional Studies, Centre for Economic and Regional Studies, Hungarian Academy of Sciences; Budaörsi út 45., H-1112 Budapest, Hungary; senior lecturer, Department of Social and Economic Geography, Eötvös Loránd University; Pázmány P. sétány 1/c., H-1117 Budapest, Hungary; czirfusz@rkk.hu

Gergely TAGAI: research fellow, Institute for Regional Studies, Centre for Economic and Regional Studies, Hungarian Academy of Sciences; Budaörsi út 45., H-1112 Budapest, Hungary; tagai@rkk.hu

A Tér és Társadalom elmúlt évét a szerzőkről és lektorokról készített összefoglalón keresztül is bemutathatjuk. A szerkesztőség tagjait potenciális szerzőink gyakran kérdezik a publikálás esélyeiről, a lektorálás szigorúságáról, az elutasítási arányokról, így az elmúlt éveket ebből a szempontból is áttekintjük írásunkban.

\section{Miből gazdálkodunk? A beérkezett írások}

A szerkesztőség a Tér és Társadalom évi négy lapszámát a beérkezett írásokból készíti. A megjelent tartalmak nagyobb része a szerzők által kezdeményezett kéziratokból származik. A lektoráláson átmenő írások közül a legtöbbet maguk a szerzők küldik a szerkesztőségbe, kivéve a tematikus számokat, ahol a vendégszerkesztő szervező munkájának köszönhetően kapjuk a cikkeket. A Könyvszemle rovatot szintén leginkább a beérkező írásokból állítjuk össze (kevésbé van viszont információnk arról, hogy a megjelent írások köre mennyiben a recenzált kötetek szerzőinek szervező munkájának eredménye). A Tudományos élet rovatban a szerkesztőség aktívabban figyeli a szakmát megmozgató kér-

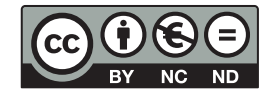


désköröket vagy rendezvényeket: itt fordulnak elő legnagyobb arányban felkérések, de természetesen mindig nyitottak vagyunk a rovatba illő írások megjelentetésére szerzői kezdeményezésre is.

A beérkezett írások köre alapvetően két csoportra osztható: az egyikbe a lektorálandó, „tanulmány” típusú cikkek tartoznak (amelyeket a Tanulmányok, a Ténykép vagy a Kitekintés rovatba soroljuk be), a másikba pedig azok, amelyek megjelentetéséről a szerkesztőség dönt (ezeket az 1. ábrán Beérkezett egyéb írás névvel illettük). Az összes beérkezett írás 75 és 87 között alakult az elmúlt öt évben, kivéve a 2015-ös évet, amikor mindössze 63 írást küldtek be szerzőink (1. ábra). A nem lektorált cikkek száma 20 és 40 között ingadozott, függően a kéziratok típusától, a szerkesztőség szervező munkájától. Például 2016-ban a 38 db, az elmúlt öt év rekordját jelentő szám a recenziók örvendetes növekedésének, a 2016. évi 2. számban a Közép-Magyarország régió kettéválásáról szóló vitának, valamint a Horizontális Műhely rovatban megjelent rövidebb közleményeknek köszönhető.

A lektorálandó cikkek körében 2013-ban rekordszámú, 59 tanulmány érkezett, a mélypont a 2015-ös év volt, amikor csupán 37 ilyen írás érkezett, 2016-ban 49 tanulmányt kaptunk. A lektorálandó tanulmányok a lektorálás eredményeképp végül vagy megjelennek, vagy nem. Az előbbi esetben a két anonim bíráló véleménye és a szerkesztőség formai kérései alapján a szerzők véglegesítik tanulmányukat, és az az olvasószerkesztés után nyomtatásban és online is megjelenik. Az ilyen, kedvezően elbírált cikkek száma 20 és 38 között ingadozott az elmúlt időszakban a beküldés éve szerint bontva. A cikkek megjelenésének éve természetesen ettől eltérhet, a 2014-ben beküldött írások kö-

1. ábra: A Tér és Társadalom szerkesztőségébe érkezett kéziratok életciklusa (2012-2016)

Life-cycle of articles submitted to Tér és Társadalom (2012-2016)

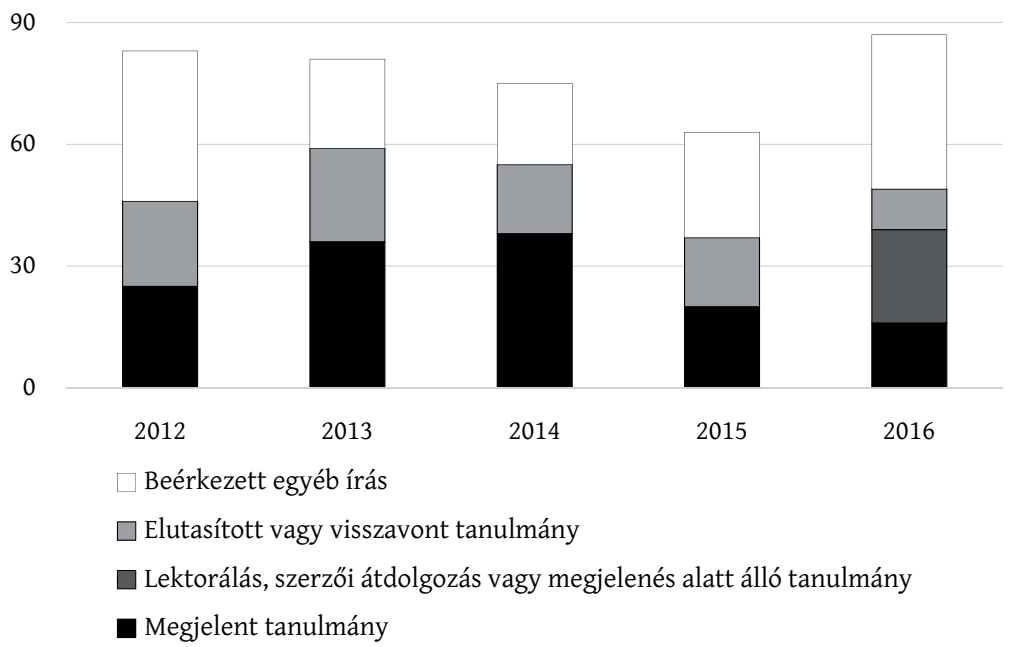


zül többet 2015-ben tudtunk megjelentetni, így a beérkező kéziratok számának ingadozásait olvasóink a megjelent lapszámokban csak tompítva és késleltetve érzékelhetik.

Utóbbi csoportba, az évi 20 db körüli, nem megjelent írás közé tartoznak azok, amelyek profilidegenek a folyóirattól vagy az alapvető formai követelményeket sem teljesítik, így lektorálás nélkül visszautasítjuk őket. Pozitívan értékeljük, hogy a lektorálás nélkül visszautasított cikkek száma 2012 és 2016 között évi 7-ről évi 3-ra csökkent, tehát szerzőink tisztában vannak a Tér és Társadalom profiljába illő témakörökkel, valamint a tudományos publikációktól elvárt legalapvetőbb követelményekkel. Az 1. ábrán az elutasított vagy visszavont kéziratok közé tartoznak előbbiek mellett azok, amelyeket az anonim bírálók nem javasoltak megjelentetésre, vagy a lektori vélemények kézhezvétele után a szerzők többszöri érdeklődésünkre sem jelentkeztek a javított kéziratukkal, esetleg a szerzők visszavonták a kéziratukat és máshol kerestek megjelenési lehetőséget. Ezeket a kéziratokat a szerkesztőségi rendszerünkben archiváljuk. A 2016-os évben beérkezett cikkek oszlopában található a 16 megjelent és a 10 elutasított tanulmány mellett 23 cikk, amelyek az év legvégén megjelenés alatt álltak (ide soroltuk az ebben a lapszámban megjelent írásokat is), a lektorálás után szerzői átdolgozáson voltak, vagy még a bírálati folyamat zajlott. Előbbutóbb belőlük is elutasított/visszavont vagy megjelent írások lesznek - remélhetőleg az utóbbi túlsúlyával.

\section{A folyóirat szerzői 2016-ban}

2016-ban a Tér és Társadalomban megjelent 54 tanulmány és egyéb írás, amelyek a Vita, a Horizontális mühely, Könyvszemle és Tudományos élet rovatokban kaptak helyet, 72 különböző szerzőtől származtak, ami megegyezik az eggyel korábbi évfolyam szerzőinek számával. Hosszabb időszakra visszatekintve is stabilnak tekinthető éves szerzői létszámunk, a korábbi évek során többször is hasonló nagyságrendet ért el a folyóiratban publikáló szerzők száma. A megjelent írások szerzőségek szerinti összetétele változatos képet mutat. Egyszerzős írásaink mellett nagyobb számban jelentek meg szerzőpárok, nagyobb szerzői kollektívák cikkei, mint ahogy tavaly tucatnyi esetben az is előfordult, hogy egy-egy szerző több alkalommal is publikált a TéT-ben.

A szerzők intézményi hovatartozása alapján elmondható, hogy 2016-ban is a hazai és külföldi főiskolákon és egyetemeken dolgozó kutatók adták a legtöbb írást a Tér és Társadalomnak. Tavaly ez a szerzőségek tekintetében az abszolút többséget is jelentette, hiszen 38 különböző szerző jelölte meg elsődleges munkahelyeként valamely felsőoktatási intézményt. Emellett 2016 során is nagyobb számban képviselték az MTA kutatóhálózatának egyes tagintézményeit a TéT-ben megjelenő szerzők. A korábbi évek gyakorlatához 
2. ábra: A Tér és Társadalom szerzőinek (munkahely szerinti) területi megoszlása, 2016 Spatial distribution of Tér és Társadalom authors (according to workplace), 2016

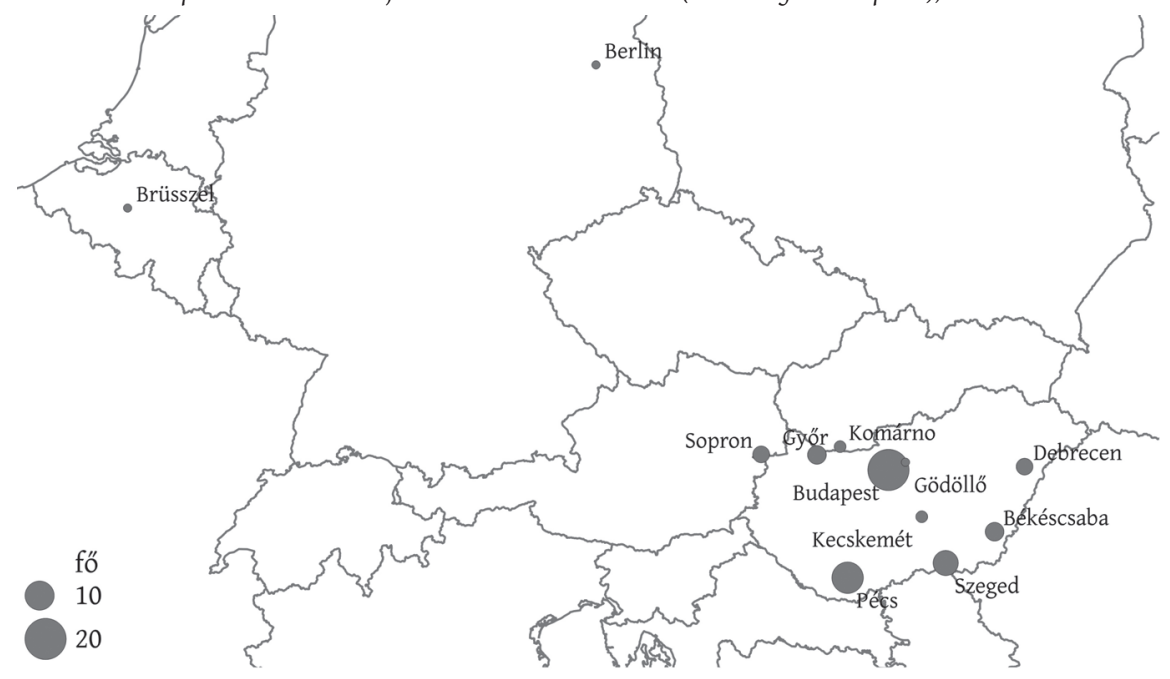

hasonlóan közülük legtöbben az MTA KRTK Regionális Kutatások Intézetében dolgozó kollégáink - szám szerint 24-en. Rajtuk kívül még négy 2016-os szerző kutat az MTA egyéb intézeteiben (Földrajztudományi Intézet, Szociológiai Intézet, Világgazdasági Intézet). Egyéb háttérrel rendelkező szerzőink jellemzően az állami és kormányzati szféra, valamint a magánszektor szakemberei.

A tavalyi év során csak elenyésző számú olyan írás jelent meg a Tér és Társadalomban, amelynek szerzője nem magyarországi munkahelyen végzi kutatóvagy tanácsadó munkáját. Ők sem külföldi szakemberek, hanem határon túli magyar kutatók (Komárno), illetve külföldi intézményeknél dolgozó hazai szerzők (Berlin, Brüsszel). Ez a szám nem lóg ki a korábbi évek által mutatott trendből, viszont azt is mutatja, hogy a nemzetközi nyitásra való törekvésben továbbra is csak részsikerek jutnak a folyóirat számára. 2016-ban a szerzők egyharmada (24 fö) érkezett budapesti kutatóhelyekről, többségükben főiskolákról és egyetemekről. Szerzőink mintegy 20\%-a (14 fö) nevezte meg munkahelyének Pécset, ahol elsősorban az MTA KRTK Regionális Kutatások Intézetének Dunántúli Tudományos Osztálya és a Pécsi Tudományegyetem különböző egységei jelentik a folyóirat szerzői bázisát. Jelentős számú szerző munkája kötődik a Szegedi Tudományegyetemhez, a tavalyi év folyamán szegedről 9 szakember munkája jelent meg a TéT-ben. Az egyéb vidéki felsőoktatási és kutatóközpontok közül Békéscsaba és Győr (5-5 fö), illetve Debrecen és Sopron (4-4 fö) táplálták jelentősebb mértékben a folyóirat szerzői bázisát. Ezen kívül, a korábbi évekhez hasonlóan, gödöllői és kecskeméti szerzők írásai is megjelentek a Tér és Társadalom hasábjain. 
2016-ban a következő személyek írásai jelentek meg a folyóiratban:

$\begin{array}{lll}\text { Artner Annamária } & \text { Gál Zoltán } & \text { Pál Viktor } \\ \text { Bajmócy Zoltán } & \text { Gébert Judit } & \text { Palaczki Botond } \\ \text { Bálint Flóra } & \text { Gerdesics Viktória } & \text { Páli-Dombi Judit } \\ \text { Bányai Orsolya } & \text { Halász Levente } & \text { Pálné Kovács Ilona } \\ \text { Baráth Etele } & \text { Hegedüs Judit } & \text { Papp-Váry Árpád Ferenc } \\ \text { Barta Attila } & \text { Józsa Viktória } & \text { Pataki György } \\ \text { Barta Györgyi } & \text { Juhász Krisztina } & \text { Pernyész Péter } \\ \text { Beluszky Pál } & \text { Karácsony Péter } & \text { Pikler Katalin } \\ \text { Bodnár Gábor } & \text { Kengyel Ákos } & \text { Póla Péter } \\ \text { Boros Lajos } & \text { Keresnyei Krisztina } & \text { Rácz Szilárd } \\ \text { Brenner János } & \text { Kiss Éva } & \text { Rechnitzer János } \\ \text { Czakó Katalin } & \text { Koós Bálint } & \text { Salamin Géza } \\ \text { Czirfusz Márton } & \text { Kovács András Donát } & \text { Schuchmann Júlia } \\ \text { Dőry Tibor } & \text { Kovács Sándor Zsolt } & \text { Szabó Pál } \\ \text { Dudás Gábor } & \text { Lengyel Imre } & \text { Szegvári Péter } \\ \text { Egedy Tamás } & \text { Lennert József } & \text { Szirmai Viktória } \\ \text { Elekes Zoltán } & \text { Málovics György } & \text { Tagai Gergely } \\ \text { Erdős Katalin } & \text { Mezei Cecília } & \text { Timár Judit } \\ \text { Fábián Attila } & \text { Nagy Erika } & \text { Tosics Iván } \\ \text { Faragó László } & \text { Nagy Gábor } & \text { Tóth Balázs István } \\ \text { Fazekas Nikolett } & \text { Nemes Nagy József } & \text { Varga Attila } \\ \text { Fehér Katalin } & \text { Németh Krisztina } & \text { Vas Zsófia } \\ \text { Fodor László } & \text { Pach János } & \text { Vaszari Tamás } \\ \text { Fónai Mihály } & \text { Páger Balázs } & \text { Zsibók Zsuzsanna }\end{array}$

\section{A folyóirat lektorai 2016-ban}

A lektorok a folyóirat színvonalának fenntartásában fontos szerepet töltenek be: ők ítélik meg a tanulmányok szakmai színvonalát, lektori véleményeik alapján dönt a szerkesztőség a beérkezett kéziratok sorsáról.

2016-ban 67 lektorral dolgoztunk együtt. Körükben a legtöbben (huszonöten) az elmúlt évekhez hasonlóan az MTA KRTK Regionális Kutatások Intézetének kutatói, az egyetemi szakemberek száma ezt majdnem elérően 24 fó volt. Az államigazgatásban, nem akadémiai kutatóhelyeken vagy a magánszférában dolgozó, illetve nyugdíjas kollégákat tavaly is felkértünk bírálatra, számuk 2016-ban 12 fö volt. Kisebb bázisát képezik a lektoroknak az MTA KRTK társintézeteinek alkalmazottai (3 fö) vagy a más MTA-kutatóközpontokban dolgozó kollégáink. A lektorálási folyamatba tehetséges PhD-hallgatókat, fiatal kutatókat és új személyeket is igyekszünk bevonni. 2016-ban jelentősen emelkedett az új lektorok száma, a 67-ből 18-an voltak olyanok, akik a szerkesztőségi rendszer 
3. ábra: A Tér és Társadalom lektorainak (munkahely szerinti) területi megoszlása, 2016 Spatial distribution of Space and Society's reviewers (according to workplace), 2016

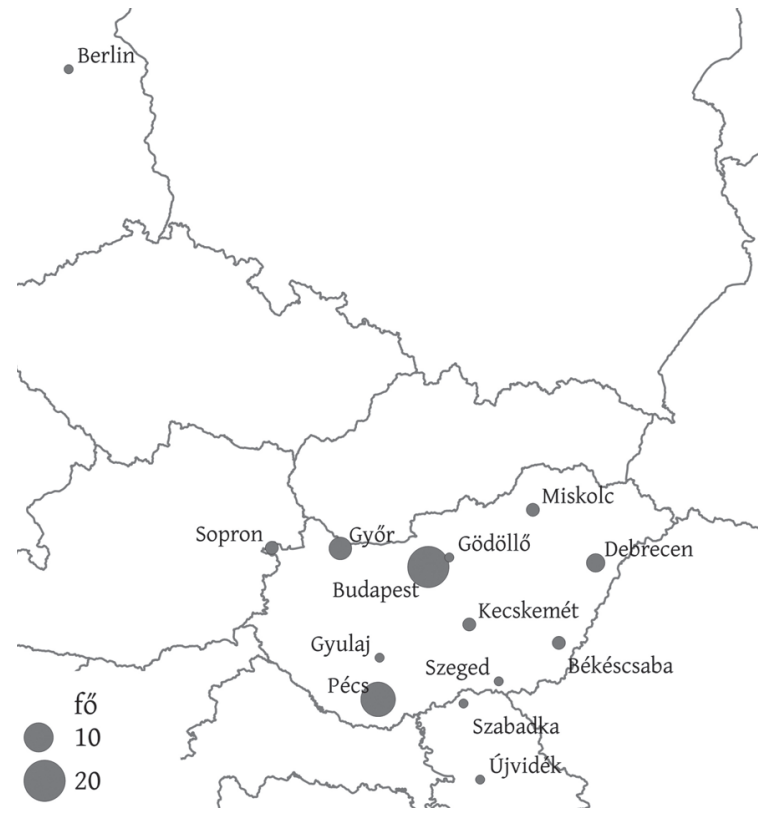

2011-es bevezetése óta még nem lektoráltak a Tér és Társadalom számára. A 2016. évi 4. szám írásait, amely Horváth Gyulára emlékezett, a szerkesztőség tagjai bírálták.

A lektorok területi megoszlásában (3. ábra) a budapesti túlsúly az elmúlt évekhez hasonló volt; 2016-ban a lektorok 43\%-a kötődött budapesti intézményhez. A második legnagyobb bázist hagyományosan Pécs nyújtja, az RKI Dunántúli Tudományos Osztálya és az egyetem révén. 4-6 lektort adott Győr és Debrecen, az 1-2 lektort adó települések zömmel felsőoktatási központok. Természetesen a lektorok körét befolyásolja a beérkezett kéziratok szerzői bázisa: mivel közvetlen kollégákat nem kérünk fel a bírálatra, ezért ha a szerzők között egy adott évben felülreprezentált egy kutatóhely vagy település, akkor az magyarázhatja a lektorok kimutatásában az adott évi csökkenést.

Továbbra is bátorítjuk a honlapon regisztrált olvasóinkat, hogy felhasználói fiókjukban adják meg kulcsszavakkal kutatási területeiket, ezzel segítve a szerkesztőség munkáját a lektorok körének további bővítésében.

A Tér és Társadalom angol nyelvű absztraktjainak alapos, körültekintő nyelvi javítását 2016-ban Novoszáth András és Thomas Richers végezték. A lektorok listájának közlésével ezúton is köszönjük mindannyiuknak a tavalyi munkát, amelyet a Tér és Társadalom számára végeztek! 
2016. január és december között lektoraink voltak:

$\begin{array}{lll}\text { A. Gergely András } & \text { Gyuris Ferenc } & \text { Pálné Kovács Ilona } \\ \text { Bajmócy Zoltán } & \text { Hajdú Zoltán } & \text { Papp-Váry Árpád Ferenc } \\ \text { Balogh Péter } & \text { Hardi Tamás } & \text { Pénzes János } \\ \text { Bányai Edit } & \text { Hegedüs József } & \text { Perger Éva } \\ \text { Barsi Boglárka } & \text { Honvári János } & \text { Póla Péter } \\ \text { Barta Györgyi } & \text { Horváth M. Tamás } & \text { Rácz Katalin } \\ \text { Beluszky Pál } & \text { Izsák Éva } & \text { Ricz András } \\ \text { Berger Viktor } & \text { Jakobi Ákos } & \text { Soltész Béla } \\ \text { Berta Péter } & \text { Jankó Ferenc } & \text { Somlyódyné Pfeil Edit } \\ \text { Bodor Ákos } & \text { Kincses Áron } & \text { Szalavetz Andrea } \\ \text { Brenner János } & \text { Kiss János Péter } & \text { Siskáné Szilasi Beáta } \\ \text { Czirfusz Márton } & \text { Koncz Imre } & \text { SzörényinéKukorelliIrén } \\ \text { Csanádi Gábor } & \text { Kovács András Donát } & \text { Szunomár Ágnes } \\ \text { Csanádi Mária } & \text { Kozma Gábor } & \text { Tagai Gergely } \\ \text { Csizmady Adrienne } & \text { Kukely György } & \text { Timár Judit } \\ \text { Dusek Tamás } & \text { Kuttor Dániel } & \text { Törőcsik Mária } \\ \text { Fábián Attila } & \text { Mezei Cecília } & \text { Uzzoli Annamária } \\ \text { Faragó László } & \text { Molnár Ernő } & \text { Váradi Monika Mária } \\ \text { Fecske Károly } & \text { Nagy Erika } & \text { Varjú Viktor } \\ \text { Finta István } & \text { Nagy Imre } & \text { Vásáry Miklós } \\ \text { Gál Zoltán } & \text { Nemes Nagy József } & \text { Virág Tünde } \\ \text { Grünhut Zoltán } & \text { Németh Nándor } & \\ \text { Győri Róbert } & \text { Ocskay Gyula } & \end{array}$

